\title{
TRABAJO SOCIAL FORENSE: PRÁCTICA BASADA EN EVIDENCIA, RETO PARA LA PROFESIÓN ${ }^{5}$
}

\section{Ana López Beltrán}

La autora de este libro lanzó un reto a profesionales del Trabajo Social forense, que es una especialidad en la cual se maneja la interrelación de los aspectos legales y el sistema de servicios sociales. El trabajador o trabajadora social forense puede brindar servicios de consultoría, educación, y adiestramiento a legisladores, abogados, y público en general. Además, ofrecer recomendaciones para el diagnóstico y el tratamiento de la población penal; también, en asuntos relacionados a la custodia de hijos(as) menores de edad, el divorcio y separación de progenitores, la delincuencia juvenil, entre otras (National Organization of Forensic Social Work, 2014; Barker, 2013).

Primero, en el libro se discute la aplicación del Modelo Práctica Basada en Evidencia, incluyendo la integración del método científico, en el quehacer diario del Profesional del Trabajo Social Forense; esto, en la mayoría de los 12 capítulos. Segundo, la autora presenta cómo el sistema de justicia evolucionó de la justicia tradicional a la justicia terapéutica. Todo esto, a la luz de los valores y cánones de ética que guían las intervenciones de Profesionales del Trabajo Social. Tercero, la doctora López Beltrán revela las opiniones, que tuvo una pequeña muestra de 13 jueces y juezas de las Salas de Familias y Menores de Puerto Rico, sobre las funciones de los(as) Profesionales del Trabajo Social como testigos periciales. La autora alimenta el libro con muchos ejemplos desde su práctica profesional como profesora y profesional del Trabajo Social Forense.

El estilo de escritura de la autora es práctico y académico. Esto hace que el libro pueda alcanzar diferentes audiencias; por

\footnotetext{
${ }^{5}$ San Juan, Puerto Rico: Autora, 2014, ISBN: 978-1-61887-386-6.

Resumen elaborado por Paul-Jesús Fericelli, Instructor del Departa-

mento de Trabajo Social, Pontificia Universidad Católica, Ponce, Puerto Rico.

${ }^{6}$ Trabajadora Social, Práctica Independiente.
} 
ejemplo, estudiantes universitarios, profesionales del Trabajo Social, abogados(as), jueces, y juezas. Este libro es indispensable para los(as) Profesionales del Trabajo Social, quienes inclinan la práctica profesional al escenario forense.

Ser practicante basado en la evidencia demanda la continua actualización del conocimiento y la metodología científica. En contraste, la autora expone que parte de los profesionales del Trabajo Social se acercaron tímidamente a la metodología de la investigación social (e.g. análisis del razonamiento estadistico; discriminación de instrumentos de medición) durante sus procesos de formación universitaria. Por tanto, una evaluación social forense puede ser cuestionada. El reto lanzado por la autora subyace en la búsqueda de la objetividad en los procesos de la evaluación social forense. El libro es un intento para alcanzar esta objetividad adoptando el Modelo Práctica Basada en Evidencia que tanto hoy se discute y cuestiona en las Salas de Familias y Menores de los Tribunales del Primera Instancia.

\section{Referencias}

Barker, Robert. (2013). The Social Work Dictionary (6 $6^{\text {th }}$ Edition). Washington, DC: National Association of Social Workers Press

National Organization of Forensic Social Work. (2014). Forensic Social Work. Recuperado de http://nofsw.org/?page id=10 